\title{
A TRADUÇÃO DE VARIANTES ORAIS DA LÍNGUA INGLESA NO PORTUGUÊS DO BRASIL: UMA APROXIMAÇÃO INICIAL
}

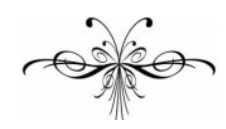

VANESSA LOPES LOURENÇO HANES

Resumo: Este artigo apresenta uma aproximação inicial sobre a maneira como o discurso oral em formato escrito é traduzido do inglês para o português brasileiro. Algumas traduções de livros e legendas de filmes foram escolhidas como corpus de análise e alguns estudos de caso conduzidos por pesquisadores brasileiros também são examinados. O objetivo deste estudo é procurar regularidades nas soluções encontradas por diferentes tradutores em suas representações das diferentes variantes orais em formato escrito. Apesar de a hipótese inicial deste estudo ter sido a de que o português brasileiro padrão seria usado regularmente nas referidas traduções, os resultados apontam para uma pluralidade de soluções usadas por profissionais de tradução, quiçá induzidas por variáveis sociológicas, tais como o impacto político/social das obras traduzidas.

Palavras-chave: Variantes linguísticas; Estudos da Tradução; discurso oral em formato escrito.

\begin{abstract}
This article presents an initial exploration of the way oral discourse in written form is translated from English into Brazilian Portuguese. The corpus consists of selected translations of books and film subtitles and a few case studies carried out by Brazilian researchers were also examined. The goal of this study is to find regularities in the solutions proposed by different translators in their representations of the written form of different oral variants. Even though the initial hypothesis of this study was that standard Portuguese would be regularly used in such translations, the results indicate a plurality of solutions are used by translation professionals, perhaps induced by sociological variables such as the political/social impact of the works translated.
\end{abstract}

Keywords: Language variants; Translation Studies; oral discourse in written form. 
$\mathrm{E}$ ste estudo visa abordar de forma introdutória, sob uma perspectiva descritiva ${ }^{1}$, a tradução de variantes orais da língua inglesa apresentadas em formato escrito para o português brasileiro. Com esse propósito, traduções de diferentes obras literárias e de legendas de obras fílmicas são consideradas, buscando encontrar regularidades na maneira como diferentes variantes do discurso oral presentes no texto-fonte são apresentadas ao público brasileiro. A hipótese inicial adotada aqui presume que as variantes do texto original são, de modo geral, traduzidas de acordo com a norma culta do português. ${ }^{2}$

Contemporaneamente, há no Brasil, como em diversas outras nações do globo, uma tradição de dar alto valor à produção cultural do exterior, em especial àquela de países de língua inglesa. Grande parte dos livros e filmes que circulam e circularam no Brasil atualmente e nas últimas décadas são produtos de origem norte-americana e inglesa, como pode ser parcialmente confirmado por dados do Index Translationum ${ }^{3}$, e a maioria da população brasileira, que não é proficiente na língua inglesa, tem acesso a essas obras estrangeiras somente através da tradução.

Porém, ao considerar essas diversas traduções, não se deve ignorar que, antes de tudo, a língua é mais do que o sistema escrito - ela é, essencialmente, oral. Como afirma Ong ( 2002, p.2), "A sociedade humana a princípio se formou com o auxílio do discurso oral, tornando-se letrada muito tarde em sua história, e inicialmente somente em certos grupos” ${ }^{\text {. }}$ E, para adicionar outro elemento de relevância a essa discussão, é importante frisar que em nenhum país fala-se somente uma língua. De acordo com Azevedo (2003, p.20), "nenhuma língua real, considerada em suas manifestações orais, é totalmente uniforme”.

Essa oralidade cheia de variações é, em algumas culturas, livremente representada também de forma escrita, inclusive em obras literárias canônicas a despeito de forças que buscam uma homogeneização e padronização nas tradições literárias. Esse é o caso das obras escritas em nações de língua inglesa. Como afirma Milton (2002), os países de língua inglesa também possuem uma tradição de literatura do proletariado. Nessas nações, essa tradição se estende também à área do cinema.

O cinema é essencialmente baseado no discurso oral. Nas obras fílmicas, os discursos do povo são comumente expressos de forma próxima àquela

\footnotetext{
${ }^{1}$ A autora entende como perspectiva descritiva aquela preconizada pelos Estudos Descritivos da Tradução, paradigma desenvolvido em meados dos anos 70 por comparatistas e estudiosos da tradução majoritariamente europeus, dentre os quais se destacam Gideon Toury, André Lefevere, José Lambert e Lieven D’hulst.

2 Norma culta é compreendida no contexto desta pesquisa conforme as concepções de Elia (1982). Esse autor explica que a norma culta da língua é aquela que "se impõe através da sanção que as classes mais cultivadas cominam às menos cultivadas” (p. 13). “A norma culta resulta do uso que as classes superiormente cultivadas impõem às menos cultivadas“ (p. 14). Ao explanar a origem da norma culta, Rocha Lima (1989, p. 6) afirma: "Fundamentam-se as regras da Gramática Normativa nas obras dos grandes escritores, em cuja linguagem as classes ilustradas põem o seu ideal de perfeição”.

${ }^{3}$ Esta informação tem como fonte consulta realizada no Index Translationum na categoria Statistics (Estatísticas), considerando a subcategoria TOP 10 languages translated in a given country (10 línguas mais traduzidas em um dado país), selecionando o Brasil como país de pesquisa.

4 "Human society first formed itself with the aid of oral speech, becoming literate very late in its history, and at first only in certain groups.”
} 
presente na realidade cotidiana. Dessa maneira, considerável volume de obras literárias ou cinematográficas originárias de culturas de língua inglesa chega às mãos dos tradutores literários e legendadores, sendo, pois, objetos de suas decisões tradutórias.

\section{Base teórica do estudo}

Dois conceitos fundamentais perpassam toda a análise desenvolvida neste artigo, e serão explanados desde o princípio devido à sua centralidade.

O primeiro deles é o conceito de 'polissistema'. Even-Zohar, um teórico israelense, elaborou no início da década de 1970 a teoria polissistêmica, também denominada teoria dos polissistemas, inicialmente vinculada à área da língua e literatura, e mais tarde atrelada a outros âmbitos socioculturais. Essa teoria entende o polissistema como um "conglomerado (ou sistema) heterogêneo, hierarquizado de sistemas que interagem para realizar um processo dinâmico de evolução dentro do polissistema como um todo” (ROMANELLI, 2003, p. 22). Ou, nas palavras do próprio Even-Zohar:

[...] o termo polissistema é mais do que simplesmente uma convenção terminológica. Seu propósito é explicitar a concepção de um sistema enquanto dinâmico e heterogêneo [...] Assim, enfatiza a multiplicidade das intersecções e consequentemente a maior complexidade do estruturamento envolvido. (1990, p. 12$)^{5}$

Buscar-se-á aqui considerar todas as traduções e os estudos consultados num contexto mais amplo, a saber, nos diversos polissistemas em que se inserem.

O segundo conceito fundamental do presente artigo é a noção de 'normas tradutórias', desenvolvida por Toury (1995). Esse autor afirma que o comportamento tradutório dentro de uma cultura tende a apresentar regularidades, chamadas por ele de 'normas tradutórias'. Essas normas são presentes em todas as sociedades, e permeiam todos os sistemas, e quando se verifica sua ocorrência torna-se possível o estabelecimento de padrões em determinado sistema. A abordagem de Toury é, portanto, behaviorista. Ao observar regularidades na conduta do tradutor é possível buscar explicá-las. Se forem desconsideradas as regularidades que podem ser atribuídas a diferenças estruturais entre as línguas envolvidas, e focalizadas as escolhas não obrigatórias, é possível focalizar restrições externas e sócio-culturais para explicar preferências recorrentes de tradutores, e são estas restrições que Toury chama de 'normas' (Hermans, 1999). Dessa maneira, quando se fala no presente estudo de encontrar regularidades ou normas, esses termos devem ser compreendidos da maneira aqui esclarecida.

Após esta elucidação dos conceitos teóricos sobre os quais o presente estudo se baseia, e antes de abordar a forma como os tradutores têm lidado com a tradução de variantes linguísticas no Brasil, será traçado um breve perfil do contexto linguístico e cultural em que esses profissionais se encontram, levando em conta a variação linguística em território nacional.

\footnotetext{
5 “ $[\ldots]$ the term polysystem is more than just a terminological convention. Its purpose is to make explicit the conception of a system as dynamic and heterogeneous [...] It thus emphasizes the multiplicity of intersections and hence the greater complexity of structuredness involved.”
} 


\section{A variação linguística no Brasil}

O Brasil é extremamente rico linguisticamente. Num território tão amplo, isso seria de se esperar. Como afirma Hobsbawm (1996, p.1068),

Historicamente, a coexistência de povos de diferentes línguas e culturas é normal; ou melhor, nada é menos comum do que países habitados exclusivamente por pessoas de uma língua e cultura uniformes. 6

O linguista Marcos Bagno (2011) afirma que o Brasil é um dos maiores centros de multiplicidade linguística do mundo, revelando que há mais de 190 línguas faladas em nosso território. É nesse contexto multilíngue que procuramos situar as variações do português e sua presença na produção cultural nacional.

No cenário brasileiro, há uma prática bem-estabelecida de representar em programas de televisão, em especial em novelas, diferentes variações do português brasileiro. Poder-se-ia discutir que essas representações são caricatas, ou até preconceituosas, mas, independentemente disso, o fato é que o público brasileiro está habituado a tal abordagem da língua em veículos de comunicação essencialmente orais. De igual modo, o cinema nacional sempre costumou retratar os diferentes falares presentes na nação.

Com relação à literatura brasileira, na popular são encontradas diversas expressões de variações da língua padrão. ${ }^{7}$ Como exemplo característico poderia ser mencionada a bem conhecida e tradicional literatura de cordel do nordeste, perpassada por traços regionalistas. E mesmo algumas obras de nosso cânone literário foram compostas com elementos de variação linguística, ainda que não representassem necessariamente uma variedade linguística específica. Um bom exemplo disso seria Grande Sertão Veredas de Guimarães Rosa. Podem ser consideradas também as histórias em quadrinhos do personagem Chico Bento, veiculadas no país desde 1963, e que têm sido muito bem recebidas pelo público infantil, nas quais, segundo afirma Bagno (2011) em entrevista concedida à revista In-Traduções, ${ }^{8}$ é apresentado um pseudo-dialeto caipira.

Porém, esse tipo de abordagem que dá margem a representações de elementos orais divergentes da norma culta em materiais escritos não foi sempre presente em território brasileiro. Ao contrário, como coloca Moreira (2008, p.01):

A língua padrão foi, pelo menos até o início do século XX, a base da literatura ocidental em geral e brasileira em particular. Mesmo que o escritor tivesse a licença poética para inventar sons, palavras, sintaxes e sentidos novos, ou seja, para se desviar das normas cultas da língua, não era comum a aproximação de uma variedade falada menos prestigiada da língua.

\footnotetext{
6 "Historically, the coexistence of peoples of different languages and cultures is normal; or, rather, nothing is less common than countries inhabited exclusively by people of a single uniform language and culture.”

7 O conceito de 'língua padrão' adotado aqui é, de certo modo, sinônimo do conceito de 'norma culta’ apresentado anteriormente. Milroy (2011) explica que a variedade padrão da língua é em geral equiparada à sua variedade de maior prestígio.

${ }^{8}<$ http://www.incubadora.ufsc.br/index.php/intraducoes >
} 
A preocupação com a questão da variação no Brasil tem sido muito presente nos últimos anos, o que pode ser atestado, por exemplo, pelas obras do linguista Marcos Bagno publicadas na última década, tais como A norma oculta: língua e poder na sociedade brasileira (2003), A língua de Eulália (2008), Língua materna: letramento, variação e ensino (2002, em conjunto com Michael Stubbs e Gilles Gagné), além dos escritos de autores tais como Possenti, cuja obra Por que (não) ensinar gramática na escola, de 1996, tem sido amplamente citada e debatida. Existiu recentemente, inclusive, a proposta por parte do Ministério da Educação de adoção de material didático que contemplasse e respeitasse diferentes formas de falar, para além daquela prescrita pela norma culta: a utilização do livro didático de língua portuguesa Por uma vida melhor, de 2011, de autoria de Heloísa Ramos ${ }^{9}$, que seria adotado no ensino de língua portuguesa para jovens e adultos. No entanto, por conta de sua abordagem didática, que não condena o uso do português não padrão, houve uma grande polêmica incitada por veículos de comunicação de massa de toda a nação, e a obra foi alvo de críticas extremamente severas por parte de vários setores da sociedade brasileira. ${ }^{10}$

Tal polêmica demonstra que apesar de a variante oral ser bem-aceita há décadas na televisão, em expressões culturais orais, e até em algumas expressões menos "prestigiadas” do português escrito (ex: o cordel), sua aceitação em certos setores de nosso polissistema linguístico ainda é restrita.

\section{A apresentação das variantes orais da língua inglesa ao público brasileiro: alguns casos}

Para analisar a maneira como as variantes orais da língua inglesa têm sido apresentadas nas traduções brasileiras tanto de literatura quanto de cinema, foi selecionado um conjunto de obras literárias e fílmicas relevantes que pudesse nortear esta investigação. Ademais, para o enriquecimento da análise foram compilados alguns estudos de caso conduzidos por pesquisadores brasileiros que lidaram com a temática da tradução de variantes inglesas em português. Além disso, houve a tentativa de encontrar estudos que lidassem com a tradução de variações linguísticas no Brasil de forma geral, mas não houve sucesso nessa busca.

Com relação às obras literárias, o processo seletivo se deu com base em meu conhecimento prévio de obras em que já sabia haver um uso representativo de variantes linguísticas. Adotamos, a partir daí, obras nas quais a questão da variação parece ter papel central: Adventures of Huckleberry Finn (1884), de Mark Twain; The Color Purple (1983), de Alice Walker; A Clockwork Orange (1962), de Anthony Burgess; No Country for Old Men (2005), de Cormac McCarthy; e Halloween Party (1969), de Agatha Christie.

Ao decidir quais filmes utilizar, optou-se por aqueles baseados nas obras literárias pré-selecionadas, a fim de se poder comparar as soluções tradutó-

\footnotetext{
${ }^{9}$ Ramos, Heloisa. Por uma vida melhor. Coleção viver e aprender. São Paulo: Editora Global. 2011.

10 Por exemplo, no blog do colunista Augusto Nunes, da Revista Veja, no endereço http://veja.abril.com.br/blog/augusto-nunes/tag/heloisa-ramos/page/2/, é possível encontrar as falas de colunistas de jornais renomados (Folha de São Paulo e O Globo), bem como do presidente da Academia Brasileira de Letras, Marcos Vilaça, criticando negativamente a obra de Heloísa Ramos.
} 
rias utilizadas na literatura e no cinema. Assim, escolheu-se três filmes: A Clockwork Orange (1971), The Color Purple (1985), e No Country for Old Men (2007).

Para auxiliar na análise, foram feitas consultas em motores de busca na internet, em que se utilizou locuções como "tradução de variação lingüística", "tradução de dialeto" e etc, tendo sido possível encontrar alguns estudos de caso brasileiros sobre o assunto em foco. Foram encontradas uma monografia de 2009 sobre a tradução de The Color Purple (1983); uma dissertação de 2006 sobre a tradução do dialeto literário em A Confederacy of Dunces (1980), de John Kennedy Toole; outra dissertação de 2010 sobre a tradução do dialeto de um personagem em Harry Potter and the Philosopher's Stone (1997), de J. K. Rowling; um artigo de 2011 sobre a tradução de Pygmalion (1912), de Bernard Shaw; outro artigo de 2011 sobre a tradução de 1984 (1949), de George Orwell, e um terceiro artigo de 2012 sobre a tradução de Of Mice and Men (1937), de John Steinbeck.

\section{Língua oral nas traduções de obras literárias}

Considerando que este estudo é uma aproximação inicial sobre o assunto em tela, cada obra literária foi analisada com o objetivo tão somente de permitir traçar algumas características gerais das abordagens tradutórias das variações orais em língua inglesa para o português do Brasil.

A primeira obra analisada, Adventures of Huckleberry Finn, publicada originalmente em 1884, é um caso à parte por ter sido traduzida no Brasil pelo menos por cinco vezes: em 1934, por Monteiro Lobato; possivelmente na primeira metade da década de 1950 por Alfredo Ferreira (a edição mais antiga encontrada, uma terceira edição, data de 1954); em 1961, por José Maria Machado (embora haja alegações de que esta tradução publicada pelo Clube do Livro possa ser, na verdade, uma adaptação de uma tradução de Portugal) ${ }^{11}$; em 1996, por Sergio Flaksman; e em 2011, por Rosaura Eichenberg. Toda a obra é narrada por Huckleberry Finn e traz o discurso direto dele e de Jim, os personagens principais, que se comunicam num inglês divergente da norma culta. De acordo com Milton (2002), as quatro primeiras traduções ao português brasileiro optaram por representar esse inglês como português padrão. Já a última tradução, de 2011, adota uma abordagem diferente, trazendo elementos de uma variante caipira do português brasileiro ${ }^{12}$ e uma longa nota inicial da tradutora a explicar o porquê dessa opção tradutória ${ }^{13}$. Abaixo é apresentada uma tabela comparando

\footnotetext{
${ }^{11}$ Esta possibilidade é mencionada por Denise Bottmann em seu blog “Não Gosto de Plágio”, no endereço: http://naogostodeplagio.blogspot.com.br/2011/02/huckleberry-finn-parte-ii.html.

${ }^{12}$ Aparentemente a tradutora buscou utilizar recursos do modo de falar do caipira do interior do estado de São Paulo. Várias particularidades da fala dessa população mencionadas por Bagno (20 11) são retratadas no discurso de Jim - como, por exemplo, a frequente ausência de concordância verbal e nominal, a supressão do ' $r$ ' final nos verbos no infinitivo (na página 100 lê-se: “Quando caí de cansado de tanto trabaiá e gritá...”), a supressão do 'd’ nos verbos conjugados no gerúndio (na página 101 Jim diz “tava pensano”), e a fusão do 'lh’ com a semivogal (na página 101 “joelho aparece como joeio”).

${ }^{13}$ Eichenberg explana em sua nota de tradutora que sua tradução, ao contrário das anteriores, não busca "civilizar" os personagens principais da obra, mas sim transmitir o modo de falar de Huckleberry Finn e de Jim, que é “essencialmente o modo de falar de quem se quer livre” (p. 8). A tradutora discorre sobre as dificuldades de traduzir dialetos, sobre o cuidado que se faz neces-
} 
uma passagem do texto original com quatro dentre as cinco diferentes traduções mencionadas.

\begin{tabular}{|c|c|c|c|c|}
\hline $\begin{array}{l}\text { Texto em inglês } \\
\text { (p. 40) }\end{array}$ & $\begin{array}{l}\text { Trad. de Lo- } \\
\text { bato (p. 57) }\end{array}$ & $\begin{array}{c}\text { Trad. de } \\
\text { Ferreira (p. 37) }\end{array}$ & $\begin{array}{c}\text { Trad. de } \\
\text { Flaksman (p. 61) }\end{array}$ & $\begin{array}{c}\text { Trad. de Ei- } \\
\text { chenberg (p. 58) }\end{array}$ \\
\hline $\begin{array}{l}\text { "Have you got } \\
\text { hairy arms and a } \\
\text { hairy breast, } \\
\text { Jim?” }\end{array}$ & $\begin{array}{l}\text { - E você? tem } \\
\text { pêlos nos bra- } \\
\text { ços e no pei- } \\
\text { to, Jim? Inda- } \\
\text { ouei }\end{array}$ & $\begin{array}{l}\text { - Tu tens os } \\
\text { braços e o peito } \\
\text { cabeludo, Jim? }\end{array}$ & $\begin{array}{l}\text { “E você tem pê- } \\
\text { los no braço e no } \\
\text { peito, Jim?” }\end{array}$ & $\begin{array}{l}\text { - Ocê tem bra- } \\
\text { ços e peito pe- } \\
\text { ludo, Jim? }\end{array}$ \\
\hline $\begin{array}{l}\text { “What's de use } \\
\text { to ax dat questi- } \\
\text { on? Don’ you } \\
\text { see I has?” }\end{array}$ & $\begin{array}{l}\text { - Para que } \\
\text { perguntar? } \\
\text { não está ven- } \\
\text { do com os } \\
\text { seus olhos? }\end{array}$ & $\begin{array}{l}\text { - Não, mas já } \\
\text { fui rico, e ainda } \\
\text { hei de tornar a } \\
\text { ser. Houve tem- } \\
\text { po em que eu ti- }\end{array}$ & $\begin{array}{l}\text { "Está perguntan- } \\
\text { do por quê? Você } \\
\text { sabe que sim.” }\end{array}$ & $\begin{array}{c}\text { - Pra quê fazê } \\
\text { essa pergunta? } \\
\text { Num tá veno } \\
\text { que tenho? }\end{array}$ \\
\hline $\begin{array}{c}\text { "Well,, are you } \\
\text { rich?” }\end{array}$ & $\begin{array}{l}\text { - Então você } \\
\text { é rico? }\end{array}$ & lares. Mas meti- & $\begin{array}{c}\text { "E você ficou ri- } \\
\text { co?” }\end{array}$ & $\begin{array}{c}\text { - Bem, ocê é ri- } \\
\text { co? }\end{array}$ \\
\hline $\begin{array}{l}\text { “No, but I ben } \\
\text { rich wunst, and } \\
\text { gwyne be rich } \\
\text { again. Wunst I } \\
\text { had foteen dol- } \\
\text { lars, but I tuck to } \\
\text { specalat'n', en } \\
\text { got busted out.” }\end{array}$ & $\begin{array}{l}\text { Já fui e hei de } \\
\text { ser. Já possuí } \\
\text { quatorze dó- } \\
\text { lares, mas en- } \\
\text { trei nuns ne- } \\
\text { gócios e perdi } \\
\text { tudo. }\end{array}$ & di tudo. & $\begin{array}{l}\text { “Não, mas eu já } \\
\text { fui rico um dia, e } \\
\text { ainda vou voltar a } \\
\text { ser. Eu já tive ca- } \\
\text { torze dólares, mas } \\
\text { aí resolvi investir } \\
\text { e acabei perdendo } \\
\text { tudo.” }\end{array}$ & $\begin{array}{l}\text { - Não, já fui ri- } \\
\text { co uma veiz e } \\
\text { vô sê rico de } \\
\text { novo. Uma veiz } \\
\text { eu tinha catorze } \\
\text { dólar, mas co- } \\
\text { mecei a ispeculá } \\
\text { e perdi tudo. }\end{array}$ \\
\hline
\end{tabular}

Tabela 1: Comparação de passagem do texto original e de diferentes traduções da obra literária Adventures of Huckleberry Finn

No romance policial Halloween Party, escrito em 1969 e traduzido em 2006 por Edilson Alkmin Cunha com o título A Noite das Bruxas, foi detectada a presença de variantes em alguns trechos do texto original. A variação na língua inglesa neste caso estava atrelada aos falantes de classes mais baixas da sociedade britânica, membros da criadagem. Com relação à tradução brasileira, não se percebe uma característica similar. No capítulo 16, o distanciamento entre o inglês e o português é bastante grande, pois é usada uma linguagem sofisticada, bem diferente do registro presente no original para retratar a fala da senhora Goodbody, uma empregada doméstica. Este exemplo é apresentado na tabela abaixo.

sário, e afirma crer que somente se aproximou da eficácia em reproduzir a linguagem original do livro. 


\begin{tabular}{|c|c|}
\hline Texto em inglês & Tradução \\
\hline $\begin{array}{l}\text { 'Yes, I was up there right enough, I } \\
\text { was. I always does the witches round } \\
\text { here. Vicar he complimented me last } \\
\text { year and he said as I'd done such a go- } \\
\text { od job in the pageant as he'd give me a } \\
\text { new steeple hat. A witch's hat wears } \\
\text { out just like anything else does. Yes, I } \\
\text { was right up there that day. I does the } \\
\text { rhymes, you know. I mean the rhymes } \\
\text { for the girls, using their own Christian } \\
\text { name. One for Beatrice, one for Ann } \\
\text { and all the rest of it. And I gives them } \\
\text { to whoever is doing the spirit voice and } \\
\text { they recite it out to the girl in the mir- } \\
\text { ror, and the boys, Master Nicholas and } \\
\text { young Desmond, they send the phoney } \\
\text { photographs floating down. Make me } \\
\text { die of laughing, some of it does.' (p. } \\
\text { 226) }\end{array}$ & $\begin{array}{l}\text { - Sim, eu me saí muito bem lá. Eu } \\
\text { sempre desempenho o papel de feiti- } \\
\text { ceira por aqui. O pároco me felicitou } \\
\text { no ano passado e disse que represen- } \\
\text { tei tão bem nos mistérios, que me } \\
\text { daria um chapéu de cone novo. O } \\
\text { chapéu de feiticeira se estraga como } \\
\text { qualquer outra coisa. Ah, sim, eu me } \\
\text { saí muito bem naquele dia. Eu faço } \\
\text { versos o senhor sabe? Versos para as } \\
\text { meninas, usando seus respectivos } \\
\text { nomes de batismo. Um para Beatri- } \\
\text { ce, outro para Ann. Eu os passo para } \\
\text { quem quer que esteja representando } \\
\text { a voz do espírito que os recita para a } \\
\text { menina no espelho, e os rapazes, Ni- } \\
\text { cholas e Desmond, põem a flutuar } \\
\text { fotografias com disfarces. Só me fal- } \\
\text { ta morrer de rir de algumas delas. (p. } \\
\text { 146) }\end{array}$ \\
\hline
\end{tabular}

Tabela 2: Comparação de passagem do texto original e da tradução brasileira da obra literária Hallowenn Party

No caso de No Country for Old Men, um romance policial de 2005 e publicado no Brasil em 2006 sob o título Onde os Velhos Não Têm Vez, o mesmo caso do livro anterior se repete. O texto original é totalmente baseado na fala regionalista do estado norte-americano do Texas, mas a tradução brasileira apresenta todos os personagens falando o português segundo a norma culta. Segue um exemplo para ilustrar essa afirmação.

\begin{tabular}{|c|c|}
\hline Texto em inglês & Tradução \\
\hline $\begin{array}{l}\text { You aint goin far, he said. You may } \\
\text { think you are. But you aint. } \\
\text { He quit the track altogether and wal- } \\
\text { ked out to the highest ground visible } \\
\text { holding the H\&K under his arm with } \\
\text { the safety off. He glassed the coun- } \\
\text { try to the south. Nothing. He stood } \\
\text { fingering the boar's tusk at the front } \\
\text { of his shirt. About now, he said, } \\
\text { you're shaded up somewheres wat- } \\
\text { chin your backtrack. And the chan- } \\
\text { ces of me seein you fore you see me } \\
\text { are about as close to nothin as you } \\
\text { can get without fallin in. (p. 13) }\end{array}$ & $\begin{array}{l}\text { Você não vai longe, ele disse. Pode a- } \\
\text { char que vai. Mas não. } \\
\text { Abandonou a trilha e caminhou até o } \\
\text { lugar mais alto visível segurando a } \\
\text { H\&K sob o braço destravada. Observou } \\
\text { com os binóculos a região ao sul. Nada. } \\
\text { Ficou mexendo no dente de javali que } \\
\text { havia na frente de sua camisa. A essa } \\
\text { altura, ele disse, você está escondido } \\
\text { em algum lugar de olho no seu rastro. E } \\
\text { as chances de eu ver você antes que vo- } \\
\text { cê me veja são praticamente nulas. (p. } \\
\text { 18-19) }\end{array}$ \\
\hline
\end{tabular}


A Clockwork Orange, um livro extremamente controverso ${ }^{14}$, escrito em 1962, foi traduzido no Brasil em duas ocasiões: em 1972, por Nelson Dantas, e em 2004, por Fábio Fernandes. Sob o título Laranja Mecânica, as duas traduções, embora consideravelmente diferentes, buscam representar no português brasileiro o inglês ficcional da obra, repleto do uso de um registro ficcional chamado nadsat, constituído de uma mistura do cockney britânico ${ }^{15}$ com o idioma russo. Uma sentença da primeira página do livro ilustra essa linguagem ficcional: "There was me, that is Alex, and my droogs, that is, Pete, Georgie and Dim, Dim being really dim, and we sat in the Korova Milkbar making up our rassoodocks what to do with the evening...”16 (p. 13). Na primeira tradução brasileira adota-se uma grafia aportuguesada dos itens lexicais do original, enquanto que a tradução mais recente opta por uma grafia incomum para esses itens lexicais no português. Por exemplo: Dantas traduz o termo veck (que significa algo como "sujeito") como veque, enquanto Fernandes opta por utilizar vek, mantendo o uso da letra ' $k$ '. O mesmo ocorre na tradução do nome de um dos companheiros do protagonista e narrador Alex, mencionado na passagem selecionada acima, o qual se chama Dim. Dantas traduz seu nome como Tapado, enquanto Fernandes o verte como Tosko.

Por fim, em The Color Purple, em português A Cor Púrpura, de 1983, traduzido no Brasil em 1986, a opção tradutória adotada também é a de utilizar um português divergente da norma culta, uma vez que a narrativa é feita por uma falante do inglês sulista dos negros dos Estados Unidos ${ }^{17}$. Um exemplo do original e da tradução é apresentado a seguir. Em poucas linhas é possível ver a grande carga de linguagem divergente da norma culta, em ambas as línguas:

\begin{tabular}{l|l}
\hline \multicolumn{1}{c|}{ Texto original } & \multicolumn{1}{c}{ Tradução } \\
\hline $\begin{array}{l}\text { He beat me today cause he say I } \\
\text { winked at a boy in church.I may } \\
\text { have got somethin in my eye but I } \\
\begin{array}{l}\text { didn't wink. I don't even look at } \\
\text { mens. That's the truth. (p. 7) }\end{array}\end{array}$ & $\begin{array}{l}\text { Ele me bateu hoje porque disse queu pis- } \\
\text { quei prum rapaz na igreja. Eu podia ta } \\
\text { com uma coisa no olho, mas eu num pis- } \\
\text { quei. Eu nem olho pros homem. Essa é } \\
\text { que é a verdade. (pag.14) }\end{array}$ \\
\hline
\end{tabular}

Tabela 5: Comparação de passagem do texto original e da tradução brasileira da obra literária The Color Purple

\footnotetext{
${ }^{14}$ Esta obra de Burgess é considerada controversa por seu alto teor de violência, pela linguagem insolente utilizada, e pela forma como apresenta e satiriza a natureza humana e a sociedade. Por causa de tais alegações, esse livro foi censurado nos EUA e no Brasil mais de uma vez.

${ }^{15} \mathrm{O}$ cockney é o dialeto inglês falado na área de East End de Londres, pela classe proletária.

${ }^{16} \mathrm{O}$ termo droog significa amigo, e rassodocks significa mente em nadsat.

${ }^{17}$ De acordo com dados do governo estadunidense obtidos através do site oficial do United States Census Bureau, a região sul dos Estados Unidos é composta por dezesseis estados, nos quais é falado o chamado inglês sulista norte-americano. Porém, embora de forma geral o inglês sulista seja tecnicamente classificado como um dialeto (de acordo com Johnson e Montgomery (2007)), na realidade ele engloba diversas subvariedades dialetais faladas em diferentes territórios. Dentre estas subvariedades encontra-se o inglês sulista falado pelos negros, que abrange diversas áreas.
} 


\section{Língua oral nas obras fílmicas}

Foram consideradas somente as legendas das versões em DVD dos filmes analisados. Nas legendas de A Clockwork Orange, intitulado de Laranja Mecânica, as ocorrências do inglês ficcional que caracterizam a obra literária são transpostas para um português também ficcional, com vários termos inexistentes na língua portuguesa utilizados a todo tempo, refletindo as falas em inglês do filme original. Por exemplo, na fala inicial do personagem principal, os termos make up our rassoodocks, milk plus vellocet or synthemesc or drencom são traduzidos nas legendas, respectivamente, como rassudocar e leite com velocete, sintemesque ou drencrom. Essa obra fílmica foi lançada em 1971, mas só foi liberada para exibição no Brasil em 1978 (embora tenha sido legendada em 1974), devido à censura do governo militar, por conta da temática polêmica (assim considerada especialmente pelo alto teor de violência apresentado) e de várias cenas consideradas impróprias. Uma cena ilustrativa de conteúdo considerado impróprio é aquela em que Alex é exposto por horas a fio a cenas de extrema violência, sem poder se mover ou fechar os olhos (seus olhos são mantidos abertos por um dispositivo que o impede de fechar as pálpebras), enquanto ouve sua obra musical preferida, a nona sinfonia de Beethoven. Tal "tratamento” teria como alvo curá-lo de seu comportamento delinquente.

Em The Color Purple, ou A Cor Púrpura no Brasil, filme de 1985, a fala regionalista dos personagens no original é apresentada nas legendas brasileiras com alguns traços de português divergente da norma culta como, por exemplo, o uso de Sinhô em lugar de Senhor. Porém, essas tentativas aparecem com frequência bem menor do que o número de ocorrências de variantes em inglês, e não são consistentes, uma vez que, para citar um caso, vários dos personagens utilizam conjugações do verbo estar divergentes da norma culta (tá, ta$v a$ ) em alguns momentos do filme mas não em outros.

Por fim, em No Country for Old Men, de 2007, lançado no Brasil com o título de Onde os Fracos Não Têm Vez, os diálogos originalmente com alta carga de inglês regional são apresentados ao público como português da norma culta. Não é possível detectar no português nenhuma indicação de que as falas originais trouxessem elementos marcantes do inglês texano. Abaixo são apresentados alguns exemplos.

\begin{tabular}{c|c}
\hline Fala original & Legenda utilizada \\
\hline $\begin{array}{c}\text { Ain't got no water. } \\
\text { It ain't took. }\end{array}$ & $\begin{array}{c}\text { Não tenho água. } \\
\text { Não está ocupado. } \\
\text { I said them very words. }\end{array}$ \\
\hline
\end{tabular}

Tabela 6: Comparação de fala original e de legendas brasileiras da obra fílmica No Country For Old Men 


\section{Sobre os estudos de caso levantados}

Em sua monografia sobre a tradução de The Color Purple, Bernieri (2009) expõe que na tradução dessa obra, feita por Betúlia Machado, Maria José Silveira e Peg Bodelson, usa-se um português divergente da norma culta. Ela ressalta que "os tradutores indubitavelmente valorizaram a força expressiva do dialeto, mediando e preservando uma cultura 'marginalizada'” (BERNIERI, 2009, p. 35). A autora apresenta vários exemplos dessa marginalização expressa através do dialeto em seu texto, dentre eles a sentença a seguir: "He say: Why don't you look decent? Put on something. But what I'm sposed to put on? I don't have nothing", que é traduzida como "Ele falou: Por que você num se veste direito? Bota alguma coisa. Mas que é queu tenho pra botar? Eu num tenho nada.” (exemplo apresentado na página 30 do estudo de Bernieri).

Com referência à tradução de A Confederacy of Dunces feita por Cristina Boselli em 1990 (o título utilizado no Brasil foi Uma Confraria de Tolos), Hanna (2006) afirma que a tradução disponível não apresenta nenhum traço dialetal, mas transmite um registro coloquial $^{18}$. Um exemplo desta coloquialidade apresentado pela autora segue, extraído da página 108 de sua pesquisa (a autora não apresenta o texto-fonte junto às suas citações em português, mas somente 0 texto-alvo, embora em outras ocasiões haja várias ocorrências extraídas do texto-fonte que demonstrem o uso frequente de dialeto na obra):

- Vim por causa do anúncio de faxineiro que saiu no jornal.

- É? - Lana Lee olhou para os óculos escuros. - Tem referências?

- A polícia pode lhe dar referências. Disseram que é melhor eu sentar o rabo num emprego garantido.

Ao discorrer sobre a fala do personagem Hagrid no livro "Harry Potter e a Pedra Filosofal”, traduzido por Lia Wyler, Santos (2010, p. 103) aponta que "a tradutora brasileira compensou as marcas dialetais, presentes na fala do personagem no texto original, predominantemente através das marcas de oralidade de interjeições e repetições”. Um dos exemplos fornecidos por ela se encontra na página 87, onde é encontrado um caso de uso de interjeição (a interjeição 'ora'): “Now, yer mum an' dad were as good a witch an' wizard as I ever knew” é traduzido como "Ora, sua mãe e seu pai eram os melhores bruxos que eu já conheci”.

Na análise de duas traduções de Pygmalion, uma de 1964 por Miroel Silveira e outra de 2005 por Millôr Fernandes, Fortes (2011) aponta que a opção tradutória no segundo texto foi a de representar o cockney do original através de uma língua ficcional, enquanto que a primeira tradução foi adaptada ao falar do Rio de Janeiro da época em que o texto foi traduzido. Tomando por exemplo a fala inicial da personagem principal no primeiro ato da peça, "Nah then Freddy; look wh’ y’ gowin, deah,” Silveira opta por traduzi-la como “Oh, Zé! Não en-

\footnotetext{
${ }^{18}$ Registro aqui é entendido segundo a definição de Halliday, McIntosh and Strevens (1964), autores que expõem que o registro é a categoria utilizada para descrever o que as pessoas fazem com a sua língua, dependendo do contexto em que a atividade linguística ocorre, o que determina qual tipo de língua é selecionado como apropriado.
} 
xerga onde pisa?”, e Fernandes verte a mesma fala como "Dirvagá com a loça, Ferderico. Num inxerga não, hômi?”

O artigo sobre a tradução de 1984 reporta que, na tradução ao português brasileiro, ao representar as falas da classe menos favorecida presente na narrativa de Orwell (os “proles”), o tradutor Wilson Velloso “esforçou-se para levar traços de variação à língua portuguesa, estabelecendo um diálogo constante entre as culturas brasileira e inglesa" (PACHECO, 2009, p. 47). Um exemplo apresentado por Pacheco na página 48 de seu artigo segue: “" $E$ could 'a drawned me off a pint. A ‘alf liter ain't enough. It don't satisfy. And a ' ole liter's too much. It starts my bladder running. Let alone the price.” é traduzido como "Ele bem que podia me servi uma pinta. Meio litro não chega. Não satisfais. E um litro é muito. Me faz a bixiga trabalhá. E o preço!?” Como é possível perceber, esse esforço tradutório incluiu o uso de um português divergente da norma culta e marcas de oralidade em toda a obra, apesar de o artigo também ressaltar que falta uniformidade na abordagem tradutória utilizada, pois não há consistência nas opções tradutórias utilizadas em toda a obra (por exemplo, em alguns casos opta-se pelo uso da segunda pessoa do singular para dar maior polidez às sentenças, enquanto em outras falas em que caberia o mesmo recurso ele não é utilizado).

Por fim, os autores do artigo que estuda a tradução da oralidade em $O f$ Mice and Men - obra traduzida três vezes ao português brasileiro (em 1940 por Érico Veríssimo, 1991 por Myriam Campello, e 2005 por Ana Ban), com o título de Ratos e Homens - afirmam que:

A tradução de Érico Veríssimo utiliza uma variedade linguística mais formal e que resulta em alterações mais substanciais em relação ao texto de partida, pois, apesar de conservar a coloquialidade, os efeitos da fala característica do texto em inglês são suavizados ou perdidos. Myriam Campello, por sua vez, transforma essa linguagem numa variedade que, embora permaneça coloquial e menos formal que a de Veríssimo, ainda assim soa mais "educada" do que a linguagem escolhida por Steinbeck, isto é, os falantes parecem ter um nível educacional maior do que no texto de partida. Ana Ban tenta conservar os efeitos do dialeto dos personagens (FARIA; HATJE-FAGGION, 2012, p. 62).

Abaixo é apresentada uma tabela compilando exemplos do texto original e das três traduções extraídos das páginas 61 e 62 do artigo consultado. 


\begin{tabular}{|c|c|c|c|}
\hline Texto original & Tradução de Veríssimo & Trad. de Campello & Tradução de Ban \\
\hline $\begin{array}{l}\text { 'Lennie. You gonna be } \\
\text { sick like you was last } \\
\text { night.' } \\
\text { (...) 'Tha's good,' he } \\
\text { said. 'You drink some, } \\
\text { George. You take a } \\
\text { good big drink.'(...) } \\
\text { 'I ain’t sure it's good } \\
\text { water,' he said. 'Looks } \\
\text { kinda scummy.' }\end{array}$ & $\begin{array}{l}\text { - Lennie. Vais ficar do- } \\
\text { ente como na noite pas- } \\
\text { sada. } \\
\text { (...) - Que coisa boa! - } \\
\text { disse êle. - Bebe um } \\
\text { pouco, George. Bebe } \\
\text { um gole bem grande } \\
\text { (...). } \\
\text { - Não sei se essa água é } \\
\text { boa. Parece meio es- } \\
\text { cumosa. }\end{array}$ & $\begin{array}{l}\text { - Lennie, você vai } \\
\text { ficar doente que } \\
\text { nem na noite pas- } \\
\text { sada. } \\
\text { (...) - Tá ótima. } \\
\text { Toma um pouco, } \\
\text { George. Toma um } \\
\text { bom gole (...). } \\
\text { - Não sei se essa } \\
\text { água é boa. Parece } \\
\text { meio espumosa. }\end{array}$ & $\begin{array}{l}\text { - Lennie. Ocê vai } \\
\text { se sentir mal, igual } \\
\text { na noite passada. } \\
\text { (...) - Foi bom - } \\
\text { disse. - Bebe um } \\
\text { pouco, George. } \\
\text { Bebe um golão. } \\
\text { (...) } \\
\text { - Num sei se essa } \\
\text { água é boa - disse. } \\
\text { - Parece meio } \\
\text { cheia de lodo. }\end{array}$ \\
\hline
\end{tabular}

Tabela 7: Exemplos extraídos de artigo sobre as diferentes traduções brasileiras da obra literária Of Mice and Men

\section{Buscando regularidades nas traduções da língua oral nas obras seleciona- das}

Conforme mencionado no início deste artigo, o objetivo deste estudo era analisar as obras elencadas a fim de procurar estabelecer regularidades ${ }^{19}$ ou ao menos possibilidades de regularidades - nas abordagens tradutórias adotadas diante da variação linguística da língua inglesa no Brasil. A hipótese inicial era a de que as variantes orais seriam, de modo geral, traduzidas de acordo com a norma culta do português.

Primeiramente é necessário ressaltar que, diante dos dados colhidos, já é possível concluir que não se verificou uniformidade na forma de traduzir as variações linguísticas da língua inglesa ao português do Brasil, visto que na amostra consultada foram encontrados casos de tradução utilizando o português segundo a norma culta, outros nos quais a opção foi somente a utilização de marcadores de oralidade, e ainda outras ocasiões nas quais diferentes formas de variações orais da língua portuguesa foram adotadas. Assim, a complexidade de análises futuras se mostra desde já consideravelmente alta, pois outras determinantes dos polissistemas de partida e de chegada deverão ser consideradas na busca de regularidades.

As obras literárias que apresentaram o português da norma culta e que não deram grande destaque aos marcadores de oralidade em suas traduções foram A Noite das Bruxas e Onde os Velhos Não Têm Vez, Assim, uma possível regularidade que mereceria ser investigada no futuro é a possibilidade da prevalência do uso do registro padrão para traduzir o gênero literário romance policial. Vale lembrar que o mesmo fenômeno (tradução segundo a norma culta) ocorreu com as legendas do filme Onde os Fracos Não Têm Vez, cujas falas em

\footnotetext{
${ }^{19}$ Ao mencionar 'regularidades', o que se tem em mente é o conceito de normas tradutórias desenvolvido por Toury (1995) apresentado anteriormente..
} 
inglês foram diretamente retiradas do livro de McCarthy e, portanto, tinham como base um inglês regionalista.

Dentre as demais obras literárias analisadas neste estudo, as seguintes apresentaram um português divergente da norma culta em suas traduções: A Cor Púrpura, Laranja Mecânica e As Aventuras de Huckleberry Finn. Com relação às obras mencionadas neste artigo por conta dos estudos de caso encontrados, variantes da língua portuguesa estão presentes nas traduções de Pigmalião, 1984 e Ratos e Homens. Surge aqui o questionamento: o que há de comum entre estas seis obras que justificaria a opção pelo uso situacional de um português divergente da norma culta? Talvez a resposta esteja em seu conteúdo de cunho político-social. Em A Cor Púrpura, em que são narrados em primeira pessoa os dramas pessoais de uma negra abusada em seu contexto sócio-familiar, vítima de violência física, sexual e psicológica, a autora retrata ao seu modo as diversas formas de violência às quais aquela foi submetida no contexto em que vivia, numa crítica aberta à cultura norte-americana da época. Em Laranja Mecânica, é feita uma crítica satírica à sociedade moderna. Em As Aventuras de Huckleberry Finn, há um tom de crítica social impresso por Twain a toda a narrativa. Pigmalião também lida com o preconceito linguístico atrelado ao preconceito social, uma vez que a personagem principal é uma garota pobre cuja fala é extremamente marcada por características dialetais, e que é adotada como projeto por um famoso profissional que se propõe a ensiná-la a falar de modo que suas origens não pudessem ser identificadas. 1984 é uma crítica acirrada ao totalitarismo político ocorrido no Sec. XX, que se temia assolaria o planeta num embate com as sociedades ocidentais chamadas "abertas" ou "livres". E Ratos e Homens busca retratar o contexto sociocultural da zona rural da Califórnia num dos períodos mais negros da história norte-americana - o período da Grande Depressão.

Em suma, a função social do discurso em cada uma dessas obras não parece ser negada, pois parte intrínseca de cada história. Inclusive, Rosaura Eichenberg, a tradutora responsável pela edição mais recente de As Aventuras de Huckleberry Finn, única tradução desse livro na qual o português divergente da norma culta aparece, aborda em sua nota introdutória a maneira como até aquele momento tentaram "civilizar" um personagem cuja tônica é a sua liberdade. Entretanto, por que somente nesta década surgiu o interesse em desvelar a liberdade de Huckleberry Finn através de sua fala? Haveria relação entre essa abordagem tradutória e o debate que tem sido travado com relação ao papel das variantes da língua portuguesa no contexto brasileiro, incitado por membros da academia tais como Possenti e Bagno? Seria também o caso de Ratos e Homens uma confirmação de uma nova tendência (pois assim como As Aventuras de Huckleberry Finn, somente em sua última tradução apresenta o uso da língua divergente da norma padrão)? E por que obras traduzidas na década de 70, como Laranja Mecânica, e na década de 80, como A Cor Púrpura, já apresentavam um discurso que utilizava variantes do português? Será que o momento histórico daquelas décadas foi, por algum motivo, propício a essas abordagens tradutórias?

No caso das obras fílmicas que apresentaram um português divergente da norma culta em suas legendas - Laranja Mecânica e A Cor Púrpura - houve uma divergência com relação às obras literárias, pois o primeiro filme trouxe uma alta carga de um português ficcional em suas legendas, tal como no livro, 
enquanto a presença da variante foi bastante atenuada no segundo filme em comparação à obra literária. Uma diferença marcante entre os dois filmes é que o filme Laranja Mecânica, dirigido por Stanley Kubrick, apresenta originalmente uma linguagem ficcional, enquanto a fala dos personagens de A Cor Púrpura retrata um registro real de um local e de uma época histórica reais, a região rural do estado norte-americano da Geórgia na década de 1930. Desse modo, pode ser frutífero investigar se o fato do discurso apresentado em obras fílmicas ser ficcional afeta ou não a abordagem tradutória adotada.

Com base nos estudos de caso utilizados para enriquecer este estudo, as obras literárias que não utilizaram variantes do português mas que trouxeram marcadores de oralidade abundantes foram Harry Potter e a Pedra Filosofal e Uma Confraria de Tolos. Ambas as obras são voltadas para público cujo discurso é povoado por marcadores de oralidade, a saber, crianças e adolescentes, o que poderia ser uma pista para a explicação desse aspecto em comum. Um outro viés que poderia ser investigado, portanto, seria o do uso de um discurso divergente da norma culta para públicos determinados, considerando a tolerância às variantes em determinados níveis por determinados públicos.

Um ponto que chama a atenção é o de que, considerando as obras literárias aqui abordadas e utilizadas como base para obras fílmicas ( $A$ Cor Púrpura, Onde os Velhos Não Têm Vez e Laranja Mecânica), a tradução do discurso para o português brasileiro surgiu em dois casos primeiramente nas obras literárias, e as legendas fílmicas parecem ter sido diretamente inspiradas pela abordagem tradutória adotada nos livros. Onde os Fracos Não Têm Vez, assim como o livro Onde os Velhos Não Têm Vez, utilizou majoritariamente, até onde se pôde verificar, o português da norma culta. E o filme Laranja Mecânica utilizou um português divergente da norma culta, a exemplo da obra literária homônima. Seria enriquecedor verificar se esse seria o caso em outras obras fílmicas em que se tem um discurso permeado por variantes inspiradas pelas obras literárias que lhes deram origem.

\section{Algumas conclusões iniciais sobre a tradução de variantes da língua inglesa para o público brasileiro}

Ao buscar formular algumas conclusões iniciais sobre as traduções aqui analisadas, é necessário considerar que, num nível micro, "dentro de toda tradução individual, a batalha pela melhor formulação acontece do princípio ao fim, é também parte das opções linguísticas, por exemplo, em termos de registro ou em termos de empréstimos" (LAMBERT, 2010, p. 39). ${ }^{20}$ Ou seja, as decisões individuais presentes nos textos ou legendas dos tradutores das traduções aqui analisadas também estão em jogo e devem ser pesadas em investigações ulteriores.

Ao mesmo tempo, essas individualidades não podem ser consideradas isoladamente sem se levar em conta os contextos específicos das traduções. Como ilustração, dou o exemplo de um professor universitário e tradutor que declarou numa banca de doutorado recente que, depois de longa dedicação à

\footnotetext{
20 "within every individual translation, the battle for the best formulation is going on from the beginning to the end, it is also part of the linguistic options, e.g. in terms of register or in terms of loan words."
} 
tradução da variação linguística presente numa determinada obra, teve seu árduo trabalho engavetado pela editora por não concordarem com suas opções tradutórias. Fica claro num caso como esse o quanto o tradutor está subordinado a decisões editoriais que podem revelar uma norma de sua época que influencia, ou mesmo determina, o seu fazer tradutório, ou então a aceitação do seu trabalho.

Considerando a teoria dos polissistemas proposta por Even-Zohar (1990), percebe-se que no Brasil, dentro do polissistema da literatura traduzida, a tradução da literatura de língua inglesa que utiliza variantes da língua em seus discursos é objeto de uma constante disputa no que tange à determinação da abordagem tradutória dominante. As recentes traduções e retraduções de obras literárias que utilizam o português divergente da norma culta, como no caso do discurso de Huckleberry Finn, poderiam apontar para uma futura mudança de paradigma, mas tal especulação não pode ser corroborada pela pequena amostra examinada neste estudo. Ainda assim, essa possibilidade sem dúvida se confirmará ou será refutada pelas pesquisas futuras sobre o tema.

Embora este artigo não tenha chegado a conclusões definitivas sobre as eventuais regularidades na tradução de variações da língua inglesa ao português do Brasil, o exercício aqui desenvolvido serviu para apontar caminhos futuros a serem seguidos na busca da compreensão dessa dinâmica tradutória no país. Crê-se que os questionamentos aqui levantados podem, se explorados mais a fundo, direcionar a busca por regularidades na tradução das variações linguísticas inglesas ao português do Brasil, podendo servir como ponto de partida para investigações maiores e mais sistemáticas.

Um grande limitador da pesquisa foi o fato de não serem encontrados outros estudos que abordassem a temática da tradução de variação linguística no Brasil de forma mais generalizada, tendo sido encontrados somente alguns estudos de caso.

Vanessa Lopes Lourenço Hannes vanessahanes@gmail.com Doutoranda, Universidade Federal de Santa Catarina 


\section{Referências bibliográficas}

A COR PÚRPURA. Direção: Steven Spielberg. Produção: Quincy Jones. Intérpretes: Danny Glover, Oprah Winfrey, Whoopi Goldberg e outros. Roteiro: Menno Meyjes. Música: Quincy Jones. Los Angeles: Warner Home Video, 1985. 2 DVDs (154 min), cor.

AzEVEDO, M. M. Vozes em branco e preto: a representação literária na fala nãopadrão. EDUSP, 2003,

BAGNO, M. “Entrevista”. In; In-Traduções. V. 3, n. 5, 2011, p. 209-212. Disponível em:< http://www.pget.ufsc.br/in-traducoes/edicao_5/Entrevista03Elisangela-Michelle.pdf $>$. Acesso em: 29 jan 2012.

. Entrevista para o Observatório da Imprensa. Vídeo disponível em: $<$ http://marcosbagno.com.br/site/>. Acesso em: 30 nov 2011.

. A Norma oculta: língua e poder na sociedade brasileira. São Paulo: Parábola Editorial, 2010. . A Língua de Eulália. São Paulo: Contexto, 2011.

BAGNO, M.; GAGNÉ, G.; STUBBS, M. Língua materna: letramento, variação e ensino. São Paulo: Parábola Editorial, 2002.

BERNIERI, S. R. As Deformações nas traduções dos coloquialismos em The Color Purple. 2009. 40 f. Monografia (Especialização em Estudos da Tradução), Universidade Comunitária Regional de Chapecó, Chapecó, 2009.

Burgess, A. A Clockwork Orange (e-book). W. W. Norton \& Company: 2011. . Laranja Mecânica. Trad. de Nelson Dantas. Rio de Janeiro: Arte Nova, 1972.

. Laranja Mecânica. Trad. de Fábio Fernandes. São Paulo: Editora Aleph, 2004.

Christie, A. Halloween Party (e-book). Harper Collins, 2010. A Noite das bruxas. Trad. de Edilson Alkmin Cunha. Rio de Janeiro/Porto Alegre: Nova Fronteira/L\&PM, 2006.

ELIA, H. “A Norma culta do Brasil”. In: Cultura Linguística, v. 1, n. 1, p. 13-16. Rio de Janeiro: Círculo Linguístico do Rio de Janeiro, 1982.

Even-Zohar, I. Polysystem theory. Poetics Today, Durham, v.11, n.1, p. 3-26, 1990.

FARIA, J. C.; HATJe-FAgGion, V. "O Problema da oralidade em três traduções de Of Mice and Men, de John Steinbeck”. In: Cadernos de Tradução. V. 1, n. 29, p. 53-71. Disponível em: $<$ http://www.periodicos.ufsc.br/index.php/traducao/article/view/21757968.2012v1n29p53/22752>. Acesso em: 17 out 2012.

FORTES, L. S. "Duas traduções brasileiras da peça Pygmalion de Bernard Shaw: Uma análise inicial a partir dos Estudos Descritivos da Tradução”. In; In-Traduções. V. 3, n. 4, p. 85-95. Disponível em: < http://www.pget.ufsc.br/in-traducoes/_edicao-4.php>. Acesso em: 26 nov 2011.

Halliday, M. A. K., Mcintosh, A., Strevens, P. The Linguistic Sciences and Language Teaching. London: Longman, 1964. 
Hanna, K. R. V. Tradução do dialeto literário de Burma Jones, da obra A Confederacy of Dunces, de John Kennedy Toole. 2006. 113f. Dissertação (Mestrado em Letras) - Programa de Pós-Graduação em Estudos Linguísticos e Literários em Inglês, Universidade de São Paulo, São Paulo, 2006.

HeRmans, T. Translation in systems: descriptive and system-oriented approaches explained. Manchester: Saint-Jerome, 1999.

HoBsBawm, E. "Language, Culture and National Identity”. In: Social research. 1996, 63, 4: p. 1065-1080.

JOHNSON, E.; MONTGOMERY, M. “Language in the south”. In: (Ed.). The

New encyclopedia of southern culture. Chapel Hill: The University of North Carolina Press, 2007. p. 1-27.

LAMBERT, J. “The Languages of translation keys to the dynamics of culture”. In Translation and Cultural Identity: Selected Essays in Translation and Cros-Cultural Communication. Newcastle: Cambridge Scholars Publishing, 2010. p. 33-60.

Laranja MecÂNICA. Direção: Stanley Kubrick. Produção: Stanley Kubrick. Intérpretes: Malcolm McDowell, Patrick Magee, Michael Bates e outros. Roteiro: Stanley Kubrick. Música: Wendy Carlos. Los Angeles: Warner Bros, 1971. 1 DVD (137 min), cor.

LIMA, C. H. R. Gramática normativa da língua portuguesa. Rio de janeiro, José Olympio, 1989.

Mc CARTHY, C. No country for old men (e-book). Picador: 2010. . Onde os velhos não têm vez. Trad. de Adriana Lisboa. Rio de Janeiro: Editora Objetiva, 2006.

Milroy, J. "Ideologias linguísticas e as consequências da padronização”. In: Bagno, Marcos; Lagares, Xoán Carlos (Ed.). Políticas da norma e conflitos linguísticos. São Paulo: Parábola Editorial, 2011, p. 49-88.

Milton, J. O Clube do livro e a tradução. Bauru: EDUSC, 2002.

MoreIRA, W. C. "Literatura e variedade caipira: os caipiras de Valdomiro Silveira”. In: Linguasagem. V. 4, 2008. Disponível em: <http://www.letras.ufscar.br/linguasagem/edicao04/04_019.php>. Acesso em: 01 nov 2011.

Onde Os Fracos NÃo TÊM Vez. Direção: Ethan Coen e Joel Coen. Produção: Joel Coen, Ethan Coen, Scott Rudin. Intérpretes: Tommy Lee Jones, Javier Bardem, Josh Brolin, Kelly MacDonald e outros. Roteiro: Joel Coen e Ethan Coen. Música: Carter Burwell. Los Angeles: Miramax Films, 2007. 1 DVD (122 min), widescreen, cor.

ONG, W. Orality and literacy: the technologizing of the world. New York: Routledge, 2002.

PACHECO, M. M. “A Questão da variação linguística na tradução da obra 1984 de George Orwell”. In: Caderno do Congresso Nacional de Linguística e Filologia. V. 12, N. 16, p.42-51, 2009. Disponível em: $<$ http://www.filologia.org.br/xiicnlf/16/volume_completo.pdf $>$. Acesso em: 29 nov 2011.

Possenti, S. Por que (não) ensinar gramática na escola. Campinas: Mercado de Letras, 1996. 
Romanelli, S. De Poeta a poeta: a única tradução possível? O Caso Dickinson/Virgilito. Uma análise descritiva. 2003. 115f. Dissertação (Mestrado em Letras e Linguística) - Programa de Pós-Graduação em Letras e Linguística, Instituto de Letras da Universidade Federal da Bahia, Salvador, 2003.

SAnTos, C. R. V. A Tradução da fala do personagem Hagrid para o português brasileiro e o português europeu no livro Harry Potter e a Pedra Filosofal: um estudo baseado em corpus. 2010. 134f. Dissertação (Mestrado em Estudos da Tradução) - Programa de Pós-Graduação em Estudos da Tradução. Universidade Federal de Santa Catarina, Florianópolis, 2010.

Twain, M. Adventures of Huckleberry Finn. Boston: Riverside Editions, 1958. . As aventuras de Huck. Tradução de Monteiro Lobato. São Paulo: Brasiliense, 1957. . Aventuras de Huck. Tradução de Alfredo Ferreira. Rio de Janeiro: Vecchi: 1957.

. As aventuras de Huckleberry Finn. Tradução de Sergio Flaksman. São Paulo: Ática, 1997.

. As aventuras de Huckleberry Finn. Tradução de Rosaura Eichenberg. Porto Alegre: L\&PM, 2011.

TOURY, G. Descriptive translation studies and beyond. Amsterdam; Philadelphia: John Benjamins Publishing Company, 1995.

United States Census BuREau. Census 2000. Disponível em:

<http://factfinder.census.gov//home/saff/main.html?_lang=>.Acesso em: 10 fev. 2010.

WALKER, A. The color purple. New York: Pocket Books New York, 1985. . A Cor púrpura. Tradução: Betúlia Machado, Maria José Silveira e Peg Bodelson. Rio de Janeiro: José Olympio, 2009. 